\title{
Servant Leadership dan Kepuasan Kerja terhadap Kinerja Karyawan di Lembaga Keuangan Non Bank Pontianak
}

\author{
Yulyanti Fahruna* \\ Universitas Tanjungpura
}

\begin{abstract}
This research aims to assess and obtain empirical evidence by testing different response toward servant leadership, job satisfaction on the performance of employees in non bank financial institutions of Pontianak. Non probability sampling technique in the form of purposive sampling is applied. The study was conduct 100 respondents, consist of 50 employees of PT. Pegadaian (Persero) Area Pontianak and 50 employees of PT. Finansia Multi Finance Pontianak. The result shows that among PT. Pegadaian (Persero) Area Pontianak and PT. Finansia Multi Finance Pontianak there is a difference in case of servant leadership, job satisfaction and performance of employees where as the similarity between both non bank financial institutions on Pontianak.
\end{abstract}

Keywords: servant leadership, job satisfaction, performance of employees

\section{PENDAHULUAN}

Lembaga yang bertugas menyalurkan uang atau dana dari kelompok masyarakat yang memiliki kelebihan dana pada masyarakat yang membutuhkan dana bukan hanya pihak perbankan saja melainkan ada juga lembaga keuangan lainnya yang bukan bank atau non bank memiliki kegiatan yang sama. Perbedaan dari perbankan dan lembaga keuangan non bank lainnya ini ada pada kegiatan utama yang dilakukan perbankan yaitu melakukan penghimpunan dana masyarakat dalam bentuk tabungan dan menyalurkannya dalam bentuk pinjaman.

Dalam suatu lembaga, organisasi ataupun perusahaan, peran yang dipegang oleh seorang pemimpin merupakan hal yang sangat vital karena berhasil atau tidaknya perusahaan serta kelangsungan hidup perusahaan tergantung pada kepiawaian pemimpin dalam menjalankan perusahaan tersebut. Peran seorang pemimpin tidak dapat diabaikan begitu saja, atau hanya dianggap sebagai suatu simbol belaka. Tercapainya suatu tujuan perusahaan juga tergantung pada bagaimana pemimpin itu melaksanakan tugasnya dengan baik dan membuat keputusan atau kebijakan yang mengarahkan perusahaan menuju keberhasilan. Dalam perusahaan, kepuasan kerja juga dipandang sebagai salah satu faktor yang penting dalam kehidupan individu, karena sebagian besar waktu manusia dihabiskan di lingkungan kerja. Setiap orang yang bekerja pastinya ingin

\footnotetext{
*Dosen FEB UNTAN Jurusan Manajemen. Email : sassy.yuly@ gmail.com
} 
mendapatkan kepuasan dari tempatnya bekerja. Kepuasan kerja merupakan hal yang sangat individual, karena setiap individu memiliki tingkat kepuasan yang berbeda-beda berdasarkan prinsip dan nilai yang berlaku pada individu tersebut.

Kinerja karyawan juga merupakan hal yang penting dalam kontribusi pada perusahaan. Perbaikan kinerja individu maupun kelompok menjadi pusat perhatian dalam upaya meningkatkan kinerja organisasi (Mathis \& Jackson, 2002). Akan tetapi dalam kenyataannya, tidak semuanya bisa berjalan sebagaimana mestinya. Pada lembaga keuangan non bank, seperti PT. Pegadaian (Persero) dan PT. Finansia Multi Finance (Kredit Plus) di area Pontianak juga mengalami adanya dinamika kinerja pada karyawannya.

Adanya karyawan yang tidak mencapai target pekerjaan dan PHK merupakan masalah dalam kinerja perusahaan-perusahan ini yang dimungkinkan dipengaruhi oleh faktor servant leadership dan kepuasan kerja karyawannya, terutama pada lembaga keuangan non bank tersebut. Adapun tujuan dari penelitian ini untuk menguji secara empiris serta menganalisis pengaruh servant leadership dan kepuasan kerja terhadap kinerja karyawan perusahaan pada lembaga keuangan non bank.

\section{TINJAUAN PUSTAKA}

Saat ini kinerja telah menjadi terminologi atau konsep yang sering dipakai berbagai kalangan, khususnya dalam rangka mendorong keberhasilan organisasi atau sumber daya manusia. Terlebih lagi, organisasi saat ini juga sudah dihadapkan pada tantangan kompetisi yang tinggi, era kompetisi pasar global, kemajuan teknologi informasi, maupun tuntutan pelanggan atau pengguna jasa layanan yang semakin kritis. Konsep kinerja pada dasarnya merupakan perubahan atau pergeseran paradigma dari konsep produktivitas.

Ada beberapa pendapat mengenai pengertian dari kinerja yang dikemukakan oleh para ahli antara lain menurut Mathis dan Jackson (2004), Kinerja adalah inti dari apa yang dilakukan atau tidak dilakukan oleh pegawai (performance is essentially what an employee does or does not to do). Maksudnya adalah kinerja karyawan dapat mempengaruhi seberapa banyak mereka memberi kontribusi kepada organisasi yang antara lain termasuk kuantitas, kualitas, jangka waktu dari output dan kehadiran di tempat kerja dan sikap kooperatif. Sedangkan Bernardin dan Rusell (2010) mendefinisikan bahwa kinerja merupakan catatan hasil yang dihasilkan dari fungsi suatu pekerjaan tertentu atau kegiatan selama satu periode (the record of outcome produced on a specified job functional or activity during specified time period). Adapun pendapat yang serupa diungkapkan oleh Gibson, Ivancevich, Donnely dan Konopaske (2006) yang mengartikan kinerja sebagai tingkat keberhasilan di dalam melaksanakan tugas serta kemampuan untuk mencapai tujuan yang telah ditetapkan. 
Kinerja dapat dikatakan baik dan sukses jika tujuan yang diinginkan dapat dicapai dengan baik. Mangkunegara (2008) menyatakan bahwa kinerja adalah hasil kerja baik secara kualitas maupun kuantitas yang dicapai oleh seseorang dalam melaksanakan tugas sesuai tanggung jawab yang diberikan. Berdasarkan dari beberapa definisi yang telah diungkapkan diatas dapat dikatakan bahwa kinerja merupakan ukuran tingkat kemampuan pegawai dilihat dari segi kualitas dan kuantitas hasil kerja yang telah dicapainya dalam satu periode tertentu baik dari sisi individu sebagai anggota dari kelompok maupun dari sisi kelompok dari suatu organisasi sehingga kinerja yang telah mencapai tujuan dan hasil sesuai dengan yang diharapkan. Untuk itu dapat dikatakan bahwa kinerja yang dilakukan tersebut juga baik dan sukses.

Penilaian kinerja karyawan adalah masalah penting bagi seluruh pengusaha. Namun demikian, kinerja yang memuaskan tidak terjadi secara otomatis dimana hal ini cenderung akan makin terjadi dengan menggunakan sistem penilaian manajemen yang baik. Dimensi ataupun indikator kinerja merupakan aspek-aspek yang menjadi ukuran dalam menilai kinerja. Ukuran-ukuran dijadikan tolak ukur dalam menilai kinerja. Dimensi ataupun pengukuran kinerja sangat diperlukan karena akan bermanfaat baik bagi banyak pihak. Adapun survei literatur mengenai dimensi atau indikator yang menjadi ukuran kinerja menurut Bernardin (2001) dalam Sudarmanto (2009) ada enam kriteria, yaitu: (a) Quality, terkait dengan proses atau hasil mendekati sempurna/ideal dalam memenuhi maksud atau tujuan; (b) Quantity, terkait dengan satuan jumlah atau kuantitas yang dihasilkan; (c) Timeless, terkait dengan waktu yang diperlukan dalam menyelesaikan aktivitas atau menghasilkan produk; (d) Cost-effectiveness, terkait dengan tingkat penggunaan sumber-sumber organisasi (orang, uang, material, teknologi) dalam mendapatkan atau memperoleh hasil atau pengurangan pemborosan dalam penggunaan sumber-sumber organisasi; (e) Need for supervision, terkait dengan kemampuan individu dapat menyelesaikan pekerjaan atau fungsi-fungsi pekerjaan tanpa asistensi pimpinan atau intervensi pengawasan pimpinan; dan (f) Interpersonal impact, terkait dengan kemampuan individu dalam meningkatkan perasaan harga diri, keinginan baik, dan kerjasama di antara sesama pekerja dan anak buah.

Fungsi pemimpin adalah untuk menggerakkan pengikut agar mereka mau mengikuti atau menjalankan apa yang diperintahkan atau yang diinginkan pemimpin. Ada orang-orang tertentu yang memang dilahirkan dengan bakat sebagai pemimpin, tetapi ada juga yang sifat kepemimpinannya diciptakan dalam suatu proses. Akan tetapi kualitas dari pemimpin pada umumnya didapat dan dibentuk bukan dengan cara yang instan, melainkan melalui suatu proses yang memerlukan waktu dan upaya yang kuat.

Kepemimpinan yang melayani (servant leadership) merupakan suatu tipe atau model kepemimpinan yang dikembangkan untuk mengatasi krisis kepemimpinan yang dialami oleh suatu masyarakat atau bangsa. Servant leadership memiliki kelebihan karena hubungan antara pemimpin dengan bawahan berorientasi pada sifat melayani dengan standar moral spiritual. Pemimpin yang memiliki sifat ini mempunyai 
tanggungjawab untuk melayani kepentingan bawahan agar mereka menjadi lebih sejahtera. Servant leadership dapat diterapkan pada semua bidang profesi, organisasi, lembaga, perusahaan, dan pemerintahan karena bersifat pelayanan ini bersifat universal. Pemimpin yang melayani dapat mempengaruhi produktivitas dalam situasi nyata suatu organisasi. Servant leadership yang berorientasi pada kepemimpinan yang melayani, berbasis pengetahuan, partisipatif, aspek tanggung jawab dalam proses, etika dan sosial dapat meredakan skandal atau konflik di dalam organisasi (Greenleaf, 1998). Karakteristik dari perilaku kepemimpinan yang melayani tumbuh dari nilai-nilai dan keyakinan individu. Nilai-nilai pribadi seperti keadilan dan integritas adalah variabel independen yang menggerakkan perilaku pemimpin yang melayani (Smith, 2005).

Indikator yang menjadi skala pengukuran servant leadership yang dikemukakan oleh Dennis (2004) adalah: (1) Love (kasih sayang) : menggambarkan sejauh mana pemimpin bisa menganggap orang lain hanya sebagai alat untuk mencapai tujuan tapi dengan memperlakukannya seperti orang yang sebenarnya yang memiliki kebutuhan, keinginan, dan kehendak; (2) Empowerment (pemberdayaan): menggambarkan pada kerjasama yakni dengan mempercayakan kekuasaan pada orang lain dan mendengarkan saran dari bawahan; (3) Vision (visi): menggambarkan pada arah yang diambil oleh pemimpin organisasi pada waktu yang akan datang. Hal ini akan menginspirasi tindakan dan membentuk arah yang baik ke depannya; (4) Humality (kerendahan hati): menggambarkan pemimpin dalam menjaga kerendahan hatinya dengan menunjukkan rasa saling menghormati serta mengakui kontribusi hasil kerja bawahannya; (5) Trust (kepercayaan): menggambarkan bahwa pemimpin merupakan orang-orang yang dipilih berdasarkan dari kelebihan dan kemampuannya dalam mendapatkan kepercayaan tersebut.

Sedangkan untuk karakteristik servant leadership lainnya yang dinyatakan oleh Spears (2010) antara lain : (1) Mendengarkan (listening) : servant leader mendengarkan dengan penuh perhatian kepada orang lain, mengidentifikasi dan membantu memperjelas keinginan kelompok, juga mendengarkan suara hati dirinya sendiri; (2) Empati (empathy): pemimpin yang melayani adalah mereka yang berusaha memahami rekan kerja dan mampu berempati dengan orang lain; (3) Penyembuhan (healing): servant leader mampu menciptakan penyembuhan emosional dan hubungan dirinya, atau hubungan dengan orang lain, karena hubungan merupakan kekuatan untuk transformasi dan integrasi; (4) Kesadaran (awareness): kesadaran untuk memahami isu-isu yang melibatkan etika, kekuasaan, dan nilai-nilai, melihat situasi dari posisi yang seimbang yang lebih terintegrasi; (5) Persuasi (persuasion): pemimpin yang melayani berusaha meyakinkan orang lain daripada memaksa kepatuhan. Ini adalah satu hal yang paling membedakan antara model otoriter tradisional dengan servant leadership; (6) Konseptualisasi (conceptualization): kemampuan melihat masalah dari perspektif konseptualisasi berarti berfikir secara jangka panjang atau visioner dalam basis yang lebih luas; (7) Kejelian (foresight) : jeli atau teliti dalam memahami pelajaran dari masa 
lalu, realitas saat ini, dan kemungkinan konsekuensi dari keputusan untuk masa depan; (8) Keterbukaan (stewardship): menekankan keterbukaan dan persuasi untuk membangun kepercayaan dari orang lain; (9) Komitmen untuk pertumbuhan (commitment to the growth of people): tanggung jawab untuk melakukan usaha dalam meningkatkan pertumbuhan profesional karyawan dan organisasi; dan yang terakhir (10) Membangun komunitas (building community): mengidentifikasi cara untuk membangun komunitas.

Liden, Wayne, Zhao dan Henderson (2008) juga menyebutkan 3 hasil (outcomes) dari servant leadership. Outcomes tersebut yaitu follower performance and growth, organizational performance, dan societal impact. Servant leadership dapat meningkatkan kinerja karyawan, dengan cara mengakui kontribusi karyawan dan membantu karyawan untuk percaya pada potensi dirinya, dan memberi kesan menyenangkan. Berikutnya adalah organizational performance, dalam meningkatkan kinerja organisasi. Servant leadership menumbuhkan pemikiran terbuka dan memberikan kesempatan untuk mengembangkan diri. Peningkatan kemampuan akan meningkatkan kinerja dan mendukung efektivitas organisasi. Societal impact, bahwa servant leadership membawa pengaruh positif kepada masyarakat. Pemikiran terbuka, peduli, berfikir jangka panjang dan bijak dalam mengambil keputusan akan membangun kepercayaan orang-orang dan masyarakat.

Definisi kepuasan kerja menurut Martoyo (2000), kepuasan kerja adalah keadaan emosional karyawan dimana terjadi ataupun tidak terjadi titik temu antara nilai balas jasa kerja karyawan dari perusahaan/organisasi dengan tingkat nilai balas jasa yang memang diinginkan oleh karyawan yang bersangkutan. Balas jasa kerja karyawan, baik yang berupa "finansial" maupun yang "nonfinansial". Hasibuan (2006) mendefinisikan kepuasan kerja sebagai sikap emosional seseorang yang menyenangi dan mencintai pekerjaannya. Kepuasan kerja karyawan harus diciptakan sebaik mungkin supaya moral kerja, dedikasi, kecintaan, dan kedisiplinan karyawan meningkat. Kepuasan kerja dinikmati dalam pekerjaan, luar pekerjaan, dan kombinasi keduanya. Nilai-nilai pekerjaan merupakan tujuan-tujuan yang ingin dicapai dalam melakukan tugas pekerjaan. Yang ingin dicapai ialah nilai-nilai pekerjaan yang dianggap penting oleh individu. Dikatakan selanjutnya bahwa nilai-nilai pekerjaan harus sesuai atau membantu pemenuhan kebutuhan-kebutuhan dasar. Dengan demikian dapat disimpulkan bahwa kepuasan kerja merupakan hasil dari tenaga kerja yang berkaitan dengan motivasi kerja.

Cokroaminoto (2007) menyatakan ada tiga kelompok variabel yang mempengaruhi perilaku kerja dan kinerja individu, yaitu variabel individu, variabel organisasi dan variabel psikologis. Kelompok variabel individu terdiri dari variabel kemampuan dan ketrampilan, latar belakang pribadi dan demografis, seperti umur, pendidikan, masa kerja, jabatan fungsional, dan jarak tempat tinggal. Sedangkan variabel demografis mempunyai pengaruh yang tidak langsung. Menurut Gibson (2006), variabel kemampuan dan ketrampilan merupakan faktor utama yang mempengaruhi perilaku 
kerja dan kinerja individu. Kelompok variabel psikologis terdiri dari variabel persepsi, sikap, kepribadian, belajar dan motivasi. Variabel ini banyak dipengaruhi oleh keluarga, tingkat sosial, dan pengalaman kerja sebelumnya. Kelompok variabel organisasi terdiri dari variabel sumber daya, kepemimpinan, struktur dan desain pekerjaan.

Robbins (2001) menyatakan bahwa karakteristik individu yang dimiliki oleh seseorang dapat mempengaruhi produktivitas kerja seseorang. Karakteristik individu tersebut meliputi karakteristik (1) biografis, (2) kemampuan, dan (3) kepribadian. Adapun hasil penelitian yang telah dilakukan oleh Robbins yang dimensi-dimensi karakteristik individu diukur oleh Robbins menunjukkan bahwa ada pengaruh antara variabel karakteristik individu dengan kinerja karyawan, yang meliputi karakteristik biografis (umur, jenis kelamin, status kawin, dan masa kerja), keahlian dan kepribadian.

Dessler (1993) juga menyatakan bahwa kemampuan meningkatkan kepuasan kerja tergantung apakah terdapat perlakuan yang fair dan adil terhadap karyawan, kesempatan untuk menggunakan kemampuan secara penuh untuk mengoptimalkan kemampuan diri, komunikasi yang terbuka dan saling percaya antar karyawan, kesempatan untuk berperan aktif dalam pengambilan keputusan yang melibatkan pekerjaan, kompensasi yang cukup dan adil, dan lingkungan yang aman serta sehat. Sikap pemimpin yang percaya pada kemampuan bawahan dan bersedia mendengarkan (empowerment) akan menumbuhkan perilaku tanggungjawab pada organisasi secara efektif (civic virtue). Karyawan akan terdorong untuk aktif dalam menyampaikan ide, serta peduli pada keadaan perusahaan. Kedekatan dan rasa simpati dari karyawan akan tumbuh melalui sikap pemimpin yang terbuka. Hal tersebut akan menumbuhkan rasa percaya karyawan terhadap pemimpin dan perusahaan. Pemimpin yang dipercaya oleh karyawan (trust) dan sikap pemimpin yang hormat dan menghargai (humility) akan mendorong karyawan untuk bekerja produktif bahkan diluar tugasnya (conscientiousness). Karyawan akan berusaha bekerja sebaik-baiknya, dan secara sukarela melakukan peran ekstra untuk mendukung efektivitas organisasi.

\section{METODE PENELITIAN}

Obyek pada penelitian ini adalah servant leadership, kepuasan karyawan dan kinerja karyawan, dengan unit analisisnya adalah karyawan di PT. Pegadaian (Persero) Area Pontianak dan PT. Finansia Multi Finance Pontianak. Dalam penelitian ini menggunakan metode penelitian survey, sebab mencakup penilaian dari karyawan sehingga hasil survei dapat dipandang mewakili seluruh populasi atau sebagian besar karyawan pada perusahaan tersebut. Populasi dari penelitian ini adalah seluruh karyawan PT. Pegadaian (Persero) Area Pontianak dan PT. Finansia Multi Finance Pontianak yang masih aktif bekerja hingga saat ini. Pengambilan sampel dilakukan dengan teknik acak sederhana (simple random sampling). Responden yang dijadikan sampel dalam penelitian ini sebanyak 100 responden, yang terdiri dari 50 responden dari karyawan PT. 
Pegadaian (Persero) Area Pontianak dan 50 responden lagi diambil dari karyawan PT. Finansia Multi Finance Pontianak.

Jenis data yang diperoleh adalah data primer dan data sekunder. Sumber data primer adalah data yang diperoleh dari hasil penelitian secara empiris melalui penyebaran kuesioner. Sedangkan sumber data sekunder adalah data yang diperoleh melalui studi pustaka dengan mempelajari berbagai tulisan yang berhubungan dengan servant leadership, kepuasan karyawan serta kinerja karyawan dan juga data yang diperoleh dari manajemen kantor PT. Pegadaian (Persero) Area Pontianak dan PT. Finansia Multi Finance Pontianak.

Teknik pengumpulan data dilakukan dengan cara menggabungkan tiga cara yaitu interview (wawancara), penyebaran quesioner (angket), dan observasi (pengamatan). Wawancara dilakukan dengan tujuan untuk mendapatkan data awal serta informasi awal dalam hubungannya dengan subjek maupun objek penelitian. Wawancara diberikan dengan berbagai pertanyaan secara langsung yang telah disiapkan sebelumnya dengan tujuan untuk mendapatkan informasi awal mengenai permasalahan-permasalahan yang ada selama ini, kemudian hasil wawancara tersebut akan dicatat untuk guna keperluan pengolahan data sehingga jawaban yang diberikan responden lebih bersifat terbuka. Observasi dilakukan dengan cara mengadakan pengamatan langsung terhadap obyek penelitian untuk dapat melihat langsung situasi dan kondisi obyek penelitian. Sedangkan penyebaran kuesioner yang berisi beberapa bentuk pertanyaan maupun pernyataan, akan langsung disebarkan kepada para karyawan PT. Pegadaian (Persero) Area Pontianak dan PT. Finansia Multi Finance Pontianak.

Adapun variabel-variabel penelitian yang ada dijabarkan sebagai berikut:

1. Variabel Independen

Variabel Independen terdiri dari servant leadership $\left(\mathrm{X}_{1}\right)$ dan kepuasan kerja $\left(\mathrm{X}_{2}\right)$.

Servant Leadership $\left(X_{1}\right)$ : seseorang yang menjadi pelayan lebih dulu. Dimulai dari perasaan alami bahwa seseorang yang ingin melayani, harus terlebih dulu melayani. Kemudian pilihan secara sadar membawa sesorang untuk memimpin (Greenleaf,1997).

Kepuasan Kerja $\left(X_{2}\right)$ : Hasil dari persepsi karyawan mengenai seberapa baik pekerjaan mereka memberikan hal yang dinilai penting (Luthans,2006)

2. Variabel Dependen

Kinerja $(Y)$ : hasil kerja secara kualitas dan kuantitas yang dapat dihasilkan oleh seseorang karyawan dalam melaksanakan tugas sesuai dengan tanggung jawab yang diberikan kepadanya (Mangkunegara, 2005).

Untuk menganalisis perbandingan antara servant leadership, kepuasan karyawan dan kinerja karyawan pada dua lembaga keuangan non bank di Pontianak, dan menguji hipotesis yang telah dirumuskan dalam penelitian ini digunakan analisis kuantitatif berupa One Way Anova. Pada penelitian ini juga dilakukan uji validitas. Uji validitas adalah untuk mengukur sah atau valid tidaknya suatu kuesioner, yang menggambarkan 
bagaimana kuesioner (pernyataan atau item) benar-benar mampu mengukur apa yang akan diukur. Suatu kuesioner dapat dikatakan valid jika pertanyaan pada kuesioner mampu untuk mengungkapkan sesuatu yang akan diukur oleh kuesioner tersebut. Jadi dapat dikatakan semakin tinggi validitas suatu tes, maka alat tes tersebut semakin tepat mengenai sasarannya. Pada penelitian kali ini untuk mengukur validitas digunakan uji korelasi bivariate antara masing-masing skor indikator dengan total skor konstruk.

\section{Variabel Servant Leadership}

Kuesioner penelitian variabel servant leadership $\left(\mathrm{X}_{1}\right)$ terdiri atas 18 item pertanyaan. Hasil perhitungan korelasi untuk skor setiap butir pernyataan dengan total skor servant leadership $\left(\mathrm{X}_{1}\right)$ lebih dari 0,3 . Seluruh item (indikator) variabel $\mathrm{X}_{1}$ menunjukkan bahwa semua item adalah valid.

2. Variabel Kepuasan Kerja

Kuesioner penelitian variabel kepuasan kerja $\left(\mathrm{X}_{2}\right)$ terdiri atas 18 item pertanyaan. Hasil perhitungan korelasi untuk skor setiap butir pernyataan dengan total skor kepuasan kerja $\left(\mathrm{X}_{2}\right)$ lebih dari 0.3. Nilai korelasi untuk seluruh item (indikator) variabel $\mathrm{X}_{2}$ juga telah menunjukkan validitas yang baik.

3. Variabel Kinerja Karyawan

Kuesioner penelitian variabel kinerja karyawan (Y) terdiri atas 13 item pertanyaan. Hasil perhitungan korelasi untuk skor setiap butir pernyataan dengan total skor kinerja karyawan (Y) lebih dari 0.3. Nilai korelasi yang diperoleh seluruh item (indikator) variabel Y telah menghasilkan validitas yang baik.

Reliabilitas berarti tingkat kepercayaan hasil suatu pengukuran. Pengukuran yang memiliki reliabilitas yang tinggi merupakan pengukuran yang mampu memberikan hasil ukur yang terpercaya (reliabel). Reliabilitas merupakan salah satu ciri atau karakter utama instrumen pengukuran yang baik. Hasil perhitungan koefisien reliabilitas untuk masing masing variabel dapat dilihat pada Tabel 1. Berdasarkan Tabel 1 tersebut dapat diketahui bahwa masing-masing variabel Servant Leadership, Kepuasan Kerja, dan Kinerja Karyawan adalah reliabel, karena memiliki koefisien Cronbach Alpha lebih besar dari 0,6.

Tabel 1. Hasil Uji Reliabilitas

\begin{tabular}{lccc}
\hline \multicolumn{1}{c}{ Variabel } & Nilai Alpa & Cronbach Alpha & $\begin{array}{c}\text { Cronbach Alpha > Nilai } \\
\text { Alpa maka reliabel }\end{array}$ \\
\hline Servant Leadership & 0.6 & 0.887 & Reliabel \\
Kepuasan Kerja & 0.6 & 0.928 & Reliabel \\
Kinerja Karyawan & 0.6 & 0.931 & Reliabel \\
\hline
\end{tabular}




\section{TEMUAN DAN PEMBAHASAN}

\subsection{Tanggapan Responden Terhadap Variabel Servant Leadership}

Penelitian ini menggunakan 18 item pertanyaan dalam kuesioner Servant Leadership untuk mengukur tanggapan karyawan mengenai Servant Leadership yang diberikan oleh PT. Pegadaian (Persero) Area Pontianak dan PT. Finansia Multi Finance Pontianak. Hasil tanggapan terhadap Servant Leadership dapat dijelaskan pada Tabel 2 dan 3 .

Tabel 2. Tanggapan Responden Mengenai Servant Leadership Pada PT. Pegadaian (Persero) Area Pontianak

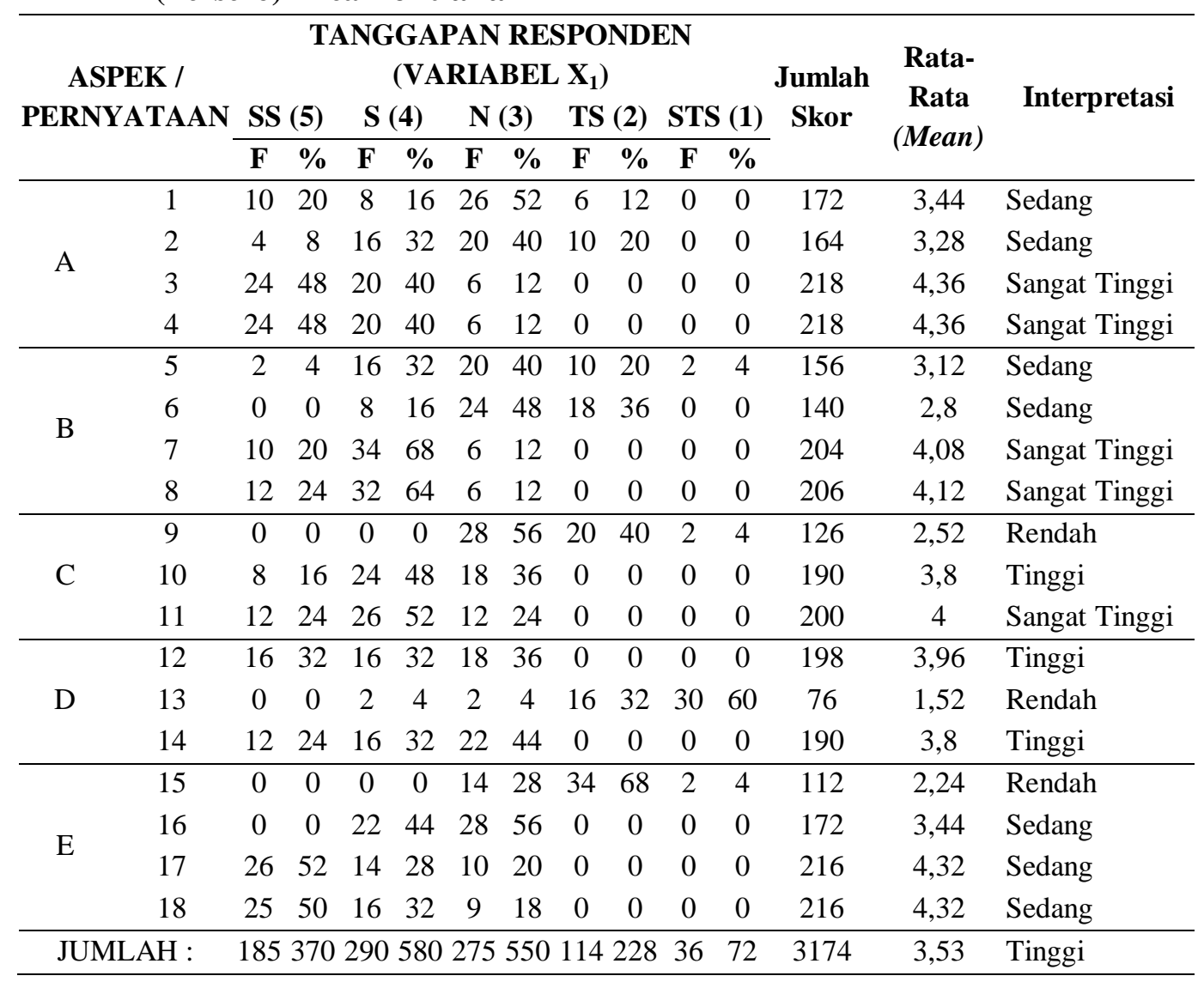

Berdasarkan Tabel 2, dapat diketahui bahwa tanggapan responden tertinggi terdapat pada item 3 dan 4 pada dimensi Love dengan nilai rata-rata sebesar 4,36 yang berarti dalam kategori Sangat Tinggi, sedangkan tanggapan responden terendah terdapat pada item 13 pada dimensi humility sebesar 1,52 yang berarti kategori Rendah. Nilai rata-rata tanggapan responden terhadap variabel servant leadership secara keseluruhan sebesar 3,53 yang bernilai kategori tinggi. 
Tabel 3. Tanggapan Responden Mengenai Servant Leadership Pada PT. Finansia Multi Finance Pontianak

\begin{tabular}{|c|c|c|c|c|c|c|c|c|c|c|c|c|c|c|}
\hline \multirow{3}{*}{\multicolumn{2}{|c|}{$\begin{array}{c}\text { ASPEK / } \\
\text { PERNYATAAN }\end{array}$}} & \multicolumn{10}{|c|}{$\begin{array}{c}\text { TANGGAPAN RESPONDEN } \\
\left(\text { VARIABEL } X_{1}\right)\end{array}$} & \multirow{3}{*}{$\begin{array}{l}\text { Jumlah } \\
\text { Skor }\end{array}$} & \multirow{3}{*}{$\begin{array}{l}\text { Rata- } \\
\text { Rata } \\
\text { (Mean) }\end{array}$} & \multirow{3}{*}{ Interpretasi } \\
\hline & & \multicolumn{2}{|c|}{ SS (5) } & \multicolumn{2}{|c|}{$S(4)$} & \multicolumn{2}{|c|}{$\mathbf{N}(3)$} & \multicolumn{2}{|c|}{ TS (2) } & \multicolumn{2}{|c|}{ STS (1) } & & & \\
\hline & & $\mathbf{F}$ & $\%$ & $\mathbf{F}$ & $\%$ & $\mathbf{F}$ & $\%$ & $\mathbf{F}$ & $\%$ & $\mathbf{F}$ & $\%$ & & & \\
\hline \multirow{4}{*}{ A } & 1 & 5 & 10 & 11 & 22 & 26 & 52 & 7 & 14 & 1 & 2 & 162 & 3,24 & Sedang \\
\hline & 2 & 2 & 4 & 18 & 36 & 22 & 44 & 7 & 14 & 1 & 2 & 163 & 3,26 & Sedang \\
\hline & 3 & 23 & 46 & 19 & 38 & 8 & 16 & 0 & 0 & 0 & 0 & 215 & 4,3 & Sangat Tinggi \\
\hline & 4 & 25 & 50 & 20 & 40 & 5 & 10 & 0 & 0 & 0 & 0 & 220 & 4,4 & Sangat Tinggi \\
\hline \multirow{4}{*}{ B } & 5 & 2 & 4 & 18 & 36 & 21 & 42 & 8 & 16 & 1 & 2 & 162 & 3,24 & Sedang \\
\hline & 6 & 1 & 2 & 14 & 28 & 24 & 48 & 11 & 22 & 0 & 0 & 155 & 3,1 & Sedang \\
\hline & 7 & 9 & 18 & 35 & 70 & 6 & 12 & 0 & 0 & 0 & 0 & 203 & 4,06 & Sangat Tinggi \\
\hline & 8 & 6 & 12 & 19 & 38 & 19 & 38 & 6 & 12 & 0 & 0 & 175 & 3,5 & Tinggi \\
\hline \multirow{3}{*}{$\mathrm{C}$} & 9 & 8 & 16 & 16 & 32 & 15 & 30 & 10 & 20 & 1 & 2 & 170 & 3,4 & Sedang \\
\hline & 10 & 12 & 24 & 27 & 54 & 11 & 22 & 0 & 0 & 0 & 0 & 201 & 4,02 & Sangat Tinggi \\
\hline & 11 & 18 & 36 & 22 & 44 & 10 & 20 & 0 & 0 & 0 & 0 & 208 & 4,16 & Sangat Tinggi \\
\hline \multirow{3}{*}{$\mathrm{D}$} & 12 & 9 & 18 & 8 & 16 & 10 & 20 & 12 & 24 & 11 & 22 & 142 & 2,84 & Sedang \\
\hline & 13 & 1 & 2 & 1 & 2 & 2 & 4 & 20 & 40 & 26 & 52 & 81 & 1,62 & Rendah \\
\hline & 14 & 12 & 24 & 26 & 52 & 12 & 24 & 0 & 0 & 0 & 0 & 200 & 4 & Sangat Tinggi \\
\hline \multirow{4}{*}{ E } & 15 & 0 & 0 & 5 & 10 & 22 & 44 & 22 & 44 & 1 & 2 & 131 & 2,62 & Sedang \\
\hline & 16 & 11 & 22 & 20 & 40 & 19 & 38 & 0 & 0 & 0 & 0 & 192 & 3,84 & Tinggi \\
\hline & 17 & 23 & 46 & 18 & 36 & 9 & 18 & 0 & 0 & 0 & 0 & 214 & 4,28 & Sangat Tinggi \\
\hline & 18 & 27 & 54 & 15 & 30 & 8 & 16 & 0 & 0 & 0 & 0 & 219 & 4,38 & Sangat Tinggi \\
\hline \multicolumn{2}{|c|}{ JUMLAH : } & 194 & 388 & 312 & 624 & 249 & 498 & 103 & 206 & 42 & 84 & 3213 & 3,57 & Tinggi \\
\hline
\end{tabular}

Berdasarkan Tabel 3, dapat diketahui bahwa tanggapan responden tertinggi terdapat pada item 4 pada dimensi Love dengan nilai rata-rata sebesar 4,4 yang berarti dalam kategori sangat tinggi, sedangkan tanggapan responden terendah terdapat pada item 13 pada dimensi Humility yang dinyatakan dengan nilai sebesar 1,62 yang berarti kategori Rendah. Nilai rata-rata tanggapan responden terhadap variabel Servant Leadership secara keseluruhan sebesar 3,57 yang bernilai kategori Tinggi.

\subsection{Tanggapan Responden Terhadap Variabel Kepuasan Kerja}

Kepuasan Kerja menunjukkan Isi Pekerjaan, Organisasi dan Manajemen, Kesempatan Promosi, Pengawasan dan Rekan Kerja. Hasil tanggapan terhadap Kepuasan Kerja pada PT. Pegadaian (Persero) Area Pontianak dapat dijelaskan pada Tabel 4 dan hasil tanggapan terhadap Kepuasan Kerja pada PT. Finansia Multi Finance Pontianak dijelaskan pada Tabel 5. 
Tabel 4. Tanggapan Responden Mengenai Kepuasan Kerja Pada PT. Pegadaian (Persero) Area Pontianak

\begin{tabular}{|c|c|c|c|c|c|c|c|c|c|c|c|c|c|c|}
\hline \multirow{3}{*}{\multicolumn{2}{|c|}{$\begin{array}{c}\text { ASPEK / } \\
\text { PERNYATAAN }\end{array}$}} & \multicolumn{10}{|c|}{$\begin{array}{c}\text { TANGGAPAN RESPONDEN } \\
\left(\text { VARIABEL } \mathrm{X}_{2}\right)\end{array}$} & \multirow{3}{*}{$\begin{array}{l}\text { Jumlah } \\
\text { Skor }\end{array}$} & \multirow{3}{*}{$\begin{array}{c}\text { Rata-Rata } \\
\text { (Mean) }\end{array}$} & \multirow{3}{*}{ Interpretasi } \\
\hline & & \multicolumn{2}{|c|}{ SS (5) } & \multicolumn{2}{|c|}{$S(4)$} & \multicolumn{2}{|c|}{$\mathbf{N}(3)$} & \multicolumn{2}{|c|}{ TS (2) } & \multicolumn{2}{|c|}{ STS (1) } & & & \\
\hline & & $\mathbf{F}$ & $\%$ & $\mathbf{F}$ & $\%$ & $\mathbf{F}$ & $\%$ & $\mathbf{F}$ & $\%$ & $\mathbf{F}$ & $\%$ & & & \\
\hline \multirow{3}{*}{$\mathrm{A}$} & 1 & 2 & 4 & 24 & 48 & 16 & 32 & 8 & 16 & 0 & 0 & 170 & 3,4 & Sedang \\
\hline & 2 & 10 & 20 & 18 & 36 & 20 & 40 & 2 & 4 & 0 & 0 & 186 & 3,72 & Tinggi \\
\hline & 3 & 10 & 20 & 24 & 48 & 12 & 24 & 4 & 8 & 0 & 0 & 190 & 3,8 & Tinggi \\
\hline \multirow{5}{*}{ B } & 4 & 48 & 96 & 2 & 4 & 0 & 0 & 0 & 0 & 0 & 0 & 248 & 4,96 & Sangat Tinggi \\
\hline & 5 & 48 & 96 & 2 & 4 & 0 & 0 & 0 & 0 & 0 & 0 & 248 & 4,96 & Sangat Tinggi \\
\hline & 6 & 26 & 52 & 18 & 36 & 6 & 12 & 0 & 0 & 0 & 0 & 220 & 4,4 & Sangat Tinggi \\
\hline & 7 & 18 & 36 & 28 & 56 & 4 & 8 & 0 & 0 & 0 & 0 & 214 & 4,28 & Sangat Tinggi \\
\hline & 8 & 14 & 28 & 18 & 36 & 16 & 32 & 2 & 4 & 0 & 0 & 194 & 3,88 & Tinggi \\
\hline \multirow{3}{*}{$\mathrm{C}$} & 9 & 12 & 24 & 26 & 52 & 12 & 24 & 0 & 0 & 0 & 0 & 200 & 4 & Sangat Tinggi \\
\hline & 10 & 14 & 28 & 28 & 56 & 8 & 16 & 0 & 0 & 0 & 0 & 206 & 4,12 & Sangat Tinggi \\
\hline & 11 & 28 & 56 & 12 & 24 & 10 & 20 & 0 & 0 & 0 & 0 & 218 & 4,36 & Sangat Tinggi \\
\hline \multirow{4}{*}{$\mathrm{D}$} & 12 & 48 & 96 & 2 & 4 & 0 & 0 & 0 & 0 & 0 & 0 & 248 & 4,96 & Sangat Tinggi \\
\hline & 13 & 24 & 48 & 18 & 36 & 8 & 16 & 0 & 0 & 0 & 0 & 216 & 4,32 & Sangat Tinggi \\
\hline & 14 & 8 & 16 & 30 & 60 & 12 & 24 & 0 & 0 & 0 & 0 & 196 & 3,92 & Tinggi \\
\hline & 15 & 4 & 8 & 12 & 24 & 14 & 28 & 18 & 36 & 2 & 4 & 148 & 2,96 & Sedang \\
\hline \multirow{3}{*}{$\mathrm{E}$} & 16 & 2 & 4 & 30 & 60 & 18 & 36 & 0 & 0 & 0 & 0 & 184 & 3,68 & Tinggi \\
\hline & 17 & 2 & 4 & 32 & 64 & 16 & 32 & 0 & 0 & 0 & 0 & 186 & 3,72 & Tinggi \\
\hline & 18 & 4 & 8 & 10 & 20 & 10 & 20 & 24 & 48 & 2 & 4 & 140 & 2,8 & Sedang \\
\hline \multicolumn{2}{|c|}{ JUMLAH : } & 322 & 644 & 334 & 668 & 182 & 364 & 58 & 116 & 4 & 8 & 3612 & 4,01 & Sangat Tinggi \\
\hline
\end{tabular}

Berdasarkan Tabel 4, dapat diketahui bahwa tanggapan responden tertinggi terdapat pada item 12 pada dimensi Pengawasan dengan nilai rata-rata sebesar 4,96 yang berarti dalam kategori Sangat Tinggi, sedangkan tanggapan responden terendah terdapat pada item 18 yang berada pada dimensi Rekan Kerja dengan nilai rata-rata sebesar 2,8 yang berarti dalam kategori Rendah. Nilai rata-rata tanggapan reponden terhadap variabel Kepuasan Kerja secara keseluruhan sebesar 4,01 yang berarti dalam kategori Sangat Tinggi.

Berdasarkan Tabel 5, dapat diketahui bahwa tanggapan responden tertinggi terdapat pada item 5 pada dimensi Organisasi \& Manajemen dan item 12 pada dimensi Pengawasan yang keduanya mempunyai nilai rata-rata sebesar 4,94 yang berarti dalam kategori Sangat Tinggi sedangkan tanggapan responden terendah terdapat pada item 18 yang berada pada dimensi Rekan dengan nilai rata-rata sebesar 2,66 yang berarti dalam kategori Sedang. Nilai rata-rata tanggapan reponden terhadap variabel Kepuasan Kerja secara keseluruhan sebesar 4,04 yang berarti dalam kategori Sangat Tinggi. 
Tabel 5. Tanggapan Responden Mengenai Kepuasan Kerja Pada PT. Finansia Multi Finance Pontianak

\begin{tabular}{|c|c|c|c|c|c|c|c|c|c|c|c|c|c|c|}
\hline \multirow{3}{*}{\multicolumn{2}{|c|}{$\begin{array}{c}\text { ASPEK / } \\
\text { PERNYATAAN }\end{array}$}} & \multicolumn{10}{|c|}{$\begin{array}{c}\text { TANGGAPAN RESPONDEN } \\
\left(\text { VARIABEL } X_{2}\right)\end{array}$} & \multirow{3}{*}{$\begin{array}{c}\text { Jumlah } \\
\text { Skor }\end{array}$} & \multirow{3}{*}{$\begin{array}{c}\text { Rata-Rata } \\
\text { (Mean) }\end{array}$} & \multirow{3}{*}{ Interpretasi } \\
\hline & & \multicolumn{2}{|c|}{ SS (5) } & \multicolumn{2}{|c|}{$S(4)$} & \multicolumn{2}{|c|}{$\mathbf{N}(3)$} & \multicolumn{2}{|c|}{ TS (2) } & \multicolumn{2}{|c|}{ STS (1) } & & & \\
\hline & & $\mathbf{F}$ & $\%$ & $\mathbf{F}$ & $\%$ & $\mathbf{F}$ & $\%$ & $\mathbf{F}$ & $\%$ & $\mathbf{F}$ & $\%$ & & & \\
\hline \multirow{3}{*}{ A } & 1 & 2 & 4 & 24 & 48 & 20 & 40 & 4 & 8 & 0 & 0 & 174 & 3,48 & Sedang \\
\hline & 2 & 13 & 26 & 23 & 46 & 10 & 20 & 4 & 8 & 0 & 0 & 195 & 3,9 & Tinggi \\
\hline & 3 & 14 & 28 & 25 & 50 & 7 & 14 & 4 & 8 & 0 & 0 & 199 & 3,98 & Tinggi \\
\hline \multirow{5}{*}{ B } & 4 & 47 & 94 & 3 & 6 & 0 & 0 & 0 & 0 & 0 & 0 & 247 & 4,94 & Sangat Tinggi \\
\hline & 5 & 47 & 94 & 2 & 4 & 1 & 2 & 0 & 0 & 0 & 0 & 246 & 4,92 & Sangat Tinggi \\
\hline & 6 & 25 & 50 & 21 & 42 & 4 & 8 & 0 & 0 & 0 & 0 & 221 & 4,42 & Sangat Tinggi \\
\hline & 7 & 22 & 44 & 25 & 50 & 3 & 6 & 0 & 0 & 0 & 0 & 219 & 4,38 & Sangat Tinggi \\
\hline & 8 & 20 & 40 & 19 & 38 & 10 & 20 & 1 & 2 & 0 & 0 & 208 & 4,16 & Sangat Tinggi \\
\hline \multirow{3}{*}{$\mathrm{C}$} & 9 & 6 & 12 & 20 & 40 & 12 & 24 & 12 & 24 & 0 & 0 & 170 & 3,4 & Sedang \\
\hline & 10 & 9 & 18 & 34 & 68 & 7 & 14 & 0 & 0 & 0 & 0 & 202 & 4,04 & Sangat Tinggi \\
\hline & 11 & 19 & 38 & 24 & 48 & 7 & 14 & 0 & 0 & 0 & 0 & 212 & 4,24 & Sangat Tinggi \\
\hline \multirow{4}{*}{$\mathrm{D}$} & 12 & 47 & 94 & 3 & 6 & 0 & 0 & 0 & 0 & 0 & 0 & 247 & 4,94 & Sangat Tinggi \\
\hline & 13 & 19 & 38 & 25 & 50 & 6 & 12 & 0 & 0 & 0 & 0 & 213 & 4,26 & Sangat Tinggi \\
\hline & 14 & 14 & 28 & 28 & 56 & 8 & 16 & 0 & 0 & 0 & 0 & 206 & 4,12 & Sangat Tinggi \\
\hline & 15 & 7 & 14 & 13 & 26 & 9 & 18 & 18 & 36 & 3 & 6 & 153 & 3,06 & Sedang \\
\hline \multirow{3}{*}{$\mathrm{E}$} & 16 & 8 & 16 & 29 & 58 & 13 & 26 & 0 & 0 & 0 & 0 & 195 & 3,9 & Tinggi \\
\hline & 17 & 6 & 12 & 32 & 64 & 12 & 24 & 0 & 0 & 0 & 0 & 194 & 3,88 & Tinggi \\
\hline & 18 & 4 & 8 & 7 & 14 & 10 & 20 & 26 & 52 & 3 & 6 & 133 & 2,66 & Sedang \\
\hline \multicolumn{2}{|c|}{ JUMLAH : } & 329 & 658 & 357 & 714 & 1392 & 278 & 69 & 138 & 6 & 12 & 3634 & 4,04 & Sangat Tinggi \\
\hline
\end{tabular}

\subsection{Tanggapan Responden Terhadap Variabel Kinerja Pegawai}

Kinerja Karyawan menunjukkan Kualitas, Kuantitas, Ketepatan Waktu, Keterampilan dan Tingkat Pengetahuan Karyawan, Standart Profesional Kerja. Penelitian ini menggunakan 13 item kuesioner Kinerja Karyawan untuk mengukur tanggapan responden mengenai Kinerja Karyawan yang diberikan oleh karyawan. Hasil tanggapan PT. Pegadaian (Persero) Area Pontianak dan PT. Finansia Multi Finance Pontianak terhadap Kinerja Karyawan dapat dijelaskan pada Tabel 6 dan 7.

Berdasarkan Tabel 6, dapat diketahui bahwa tanggapan responden tertinggi terdapat pada item 12 yang terdapat pada dimensi Standar Profesional Kerja dengan nilai rata-rata sebesar 4,12 yang berarti dalam kategori Sangat Tinggi dan tanggapan responden terendah terdapat pada item 6 pada dimensi Kuantitas dengan nilai rata-rata sebesar 2,16 yang berarti dalam kategori Rendah. Nilai rata-rata tanggapan reponden terhadap variabel Kinerja Karyawan secara keseluruhan sebesar 3.43 yang berarti dalam kategori Sedang. 
Tabel 6. Tanggapan Responden Mengenai Kinerja Karyawan Pada PT. Pegadaian (Persero) Area Pontianak

\begin{tabular}{|c|c|c|c|c|c|c|c|c|c|c|c|c|c|c|}
\hline \multirow{3}{*}{\multicolumn{2}{|c|}{$\begin{array}{c}\text { ASPEK / } \\
\text { PERNYATAAN }\end{array}$}} & \multicolumn{10}{|c|}{ TANGGAPAN RESPONDEN (VARIABEL X1) } & \multirow{3}{*}{$\begin{array}{l}\text { Jumlah } \\
\text { Skor }\end{array}$} & \multirow{3}{*}{$\begin{array}{c}\text { Rata- } \\
\text { Rata } \\
(\text { Mean })\end{array}$} & \multirow{3}{*}{ Interpretasi } \\
\hline & & \multicolumn{2}{|c|}{ SS (5) } & \multicolumn{2}{|c|}{ S (4) } & \multicolumn{2}{|c|}{$\mathbf{N}(3)$} & \multicolumn{2}{|c|}{ TS (2) } & \multicolumn{2}{|c|}{ STS (1) } & & & \\
\hline & & $\mathbf{F}$ & $\%$ & $\mathbf{F}$ & $\%$ & $\mathbf{F}$ & $\%$ & $\mathbf{F}$ & $\%$ & $\mathbf{F}$ & $\%$ & & & \\
\hline & 1 & 0 & 0 & 12 & 24 & 34 & 68 & 4 & 8 & 0 & 0 & 158 & 3,16 & Sedang \\
\hline & 2 & 0 & 0 & 22 & 44 & 22 & 44 & 6 & 12 & 0 & 0 & 166 & 3,32 & Sedang \\
\hline A & 3 & 4 & 8 & 18 & 36 & 28 & 56 & 0 & 0 & 0 & 0 & 176 & 3,52 & Tinggi \\
\hline & 4 & 0 & 0 & 2 & 4 & 26 & 52 & 22 & 44 & 0 & 0 & 130 & 2,6 & Sedang \\
\hline & 5 & 6 & 12 & 22 & 44 & 22 & 44 & 0 & 0 & 0 & 0 & 184 & 3,68 & Tinggi \\
\hline $\mathrm{P}$ & 6 & 0 & 0 & 2 & 4 & 8 & 16 & 36 & 72 & 4 & 8 & 108 & 2,16 & Rendah \\
\hline$D$ & 7 & 8 & 16 & 14 & 28 & 24 & 48 & 4 & 8 & 0 & 0 & 176 & 3,52 & Tinggi \\
\hline$C$ & 8 & 12 & 24 & 24 & 48 & 12 & 24 & 2 & 4 & 0 & 0 & 196 & 3,92 & Tinggi \\
\hline & 9 & 10 & 20 & 28 & 56 & 12 & 24 & 0 & 0 & 0 & 0 & 198 & 3,96 & Tinggi \\
\hline ) & 10 & 4 & 8 & 2 & 4 & 22 & 44 & 22 & 44 & 0 & 0 & 138 & 2,76 & Sedang \\
\hline D & 11 & 16 & 32 & 20 & 40 & 14 & 28 & 0 & 0 & 0 & 0 & 202 & 4,04 & Sangat Tinggi \\
\hline $\mathrm{F}$ & 12 & 16 & 32 & 24 & 48 & 10 & 20 & 0 & 0 & 0 & 0 & 206 & 4,12 & Sangat Tinggi \\
\hline $\mathrm{W}$ & 13 & 16 & 32 & 18 & 36 & 8 & 16 & 8 & 16 & 0 & 0 & 192 & 3,84 & Tinggi \\
\hline & $\mathrm{AH}:$ & 92 & 184 & 208 & 416 & 242 & 484 & 104 & 208 & 4 & 8 & 2230 & 3,43 & Sedang \\
\hline
\end{tabular}

Tabel 7. Tanggapan Responden Mengenai Kinerja Karyawan Pada PT. Finansia Multi Finance Pontianak

\begin{tabular}{|c|c|c|c|c|c|c|c|c|c|c|c|c|c|c|}
\hline \multirow{3}{*}{\multicolumn{2}{|c|}{$\begin{array}{c}\text { ASPEK / } \\
\text { PERNYATAAN }\end{array}$}} & \multicolumn{10}{|c|}{ TANGGAPAN RESPONDEN (VARIABEL Y) } & \multirow{3}{*}{$\begin{array}{c}\text { Jumlah } \\
\text { Skor }\end{array}$} & \multirow{3}{*}{$\begin{array}{c}\text { Rata- } \\
\text { Rata } \\
\text { (Mean) }\end{array}$} & \multirow{3}{*}{ Interpretasi } \\
\hline & & \multicolumn{2}{|c|}{ SS (5) } & \multicolumn{2}{|c|}{$\mathbf{S}(4)$} & \multicolumn{2}{|c|}{$\mathbf{N}(3)$} & \multicolumn{2}{|c|}{ TS (2) } & \multicolumn{2}{|c|}{ STS (1) } & & & \\
\hline & & $\mathbf{F}$ & $\%$ & $\mathbf{F}$ & $\%$ & $\mathbf{F}$ & $\%$ & $\mathbf{F}$ & $\%$ & $\mathbf{F}$ & $\%$ & & & \\
\hline \multirow{5}{*}{ A } & 1 & 2 & 4 & 19 & 38 & 27 & 54 & 2 & 4 & 0 & 0 & 171 & 3,42 & Sedang \\
\hline & 2 & 3 & 6 & 28 & 56 & 16 & 32 & 3 & 6 & 0 & 0 & 181 & 3,62 & Tinggi \\
\hline & 3 & 8 & 16 & 23 & 46 & 19 & 38 & 0 & 0 & 0 & 0 & 189 & 3,78 & Tinggi \\
\hline & 4 & 0 & 0 & 1 & 2 & 19 & 38 & 29 & 58 & 1 & 2 & 120 & 2,4 & Rendah \\
\hline & 5 & 6 & 12 & 28 & 56 & 16 & 32 & 0 & 0 & 0 & 0 & 190 & 3,8 & Tinggi \\
\hline \multirow{2}{*}{ B } & 6 & 0 & 0 & 1 & 2 & 7 & 14 & 38 & 76 & 4 & 8 & 105 & 2,1 & Rendah \\
\hline & 7 & 12 & 24 & 17 & 34 & 19 & 38 & 2 & 4 & 0 & 0 & 189 & 3,78 & Tinggi \\
\hline \multirow{2}{*}{$\mathrm{C}$} & 8 & 17 & 34 & 23 & 46 & 9 & 18 & 1 & 2 & 0 & 0 & 206 & 4,12 & Sangat Tinggi \\
\hline & 9 & 16 & 32 & 24 & 48 & 10 & 20 & 0 & 0 & 0 & 0 & 206 & 4,12 & Sangat Tinggi \\
\hline \multirow{2}{*}{$\mathrm{D}$} & 10 & 2 & 4 & 2 & 4 & 22 & 44 & 23 & 46 & 1 & 2 & 131 & 2,62 & Sedang \\
\hline & 11 & 11 & 22 & 30 & 60 & 9 & 18 & 0 & 0 & 0 & 0 & 202 & 4,04 & Sangat Tinggi \\
\hline \multirow{2}{*}{$\mathrm{E}$} & 12 & 15 & 30 & 30 & 60 & 5 & 10 & 0 & 0 & 0 & 0 & 210 & 4,2 & Sangat Tinggi \\
\hline & 13 & 20 & 40 & 12 & 24 & 4 & 8 & 4 & 8 & 0 & 0 & 168 & 3,36 & Sedang \\
\hline \multicolumn{2}{|c|}{ JUMLAH } & 112 & 224 & 238 & 476 & 182 & 364 & 102 & 204 & 6 & 12 & 2268 & 3,49 & Tinggi \\
\hline
\end{tabular}


Berdasarkan Tabel 7, dapat diketahui bahwa tanggapan responden tertinggi terdapat pada item 8 dan 9 yang berada pada dimensi Ketepatan Waktu dengan nilai ratarata sebesar 4,12 yang berarti dalam kategori Sangat Tinggi dan tanggapan responden terendah terdapat pada item 6 pada dimensi Kuantitas Kerja dengan nilai rata-rata sebesar 2,1 yang berarti dalam kategori Rendah. Nilai rata-rata tanggapan responden terhadap variabel Kinerja Karyawan secara keseluruhan sebesar 3,49 yang berarti dalam kategori Tinggi.

\subsection{Uji Asumsi Klasik}

Hasil pengujian normalitas sampel penelitian pada PT. Pegadaian (Persero) Area Pontianak ini disajikan pada Gambar 1. Berdasarkan hasil pengujian normalitas seperti yang terlihat pada grafik Normal P-Plot di atas, diketahui bahwa titik-titik menyebar di sekitar garis diagonal dan mengikuti arah garis diagonal. Hasil tersebut menunjukkan bahwa model regresi yang digunakan memenuhi asumsi normalitas. Hal yang sama ditunjukkan juga pada pengujian normalitas sampel penelitian pada PT. Finansia Multi Finance Pontianak yang disajikan pada Gambar 2.

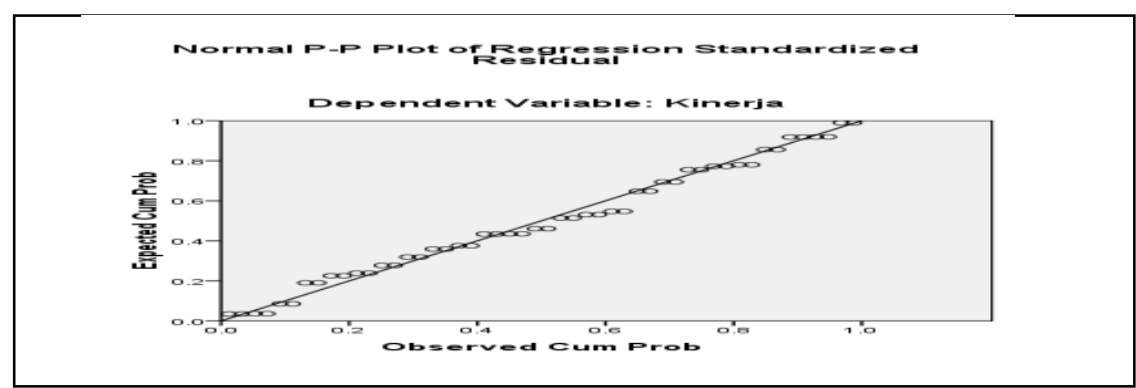

Gambar 1. Grafik Normal P-Plot PT. Pegadaian (Persero) Area Pontianak

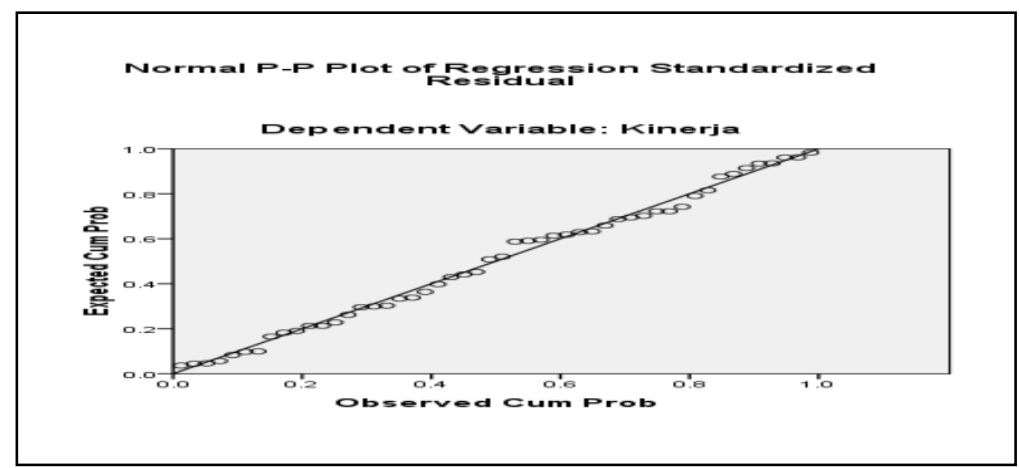

Gambar 2. Grafik Normal P-Plot PT. Finansia Multi Finance Pontianak

Berdasarkan hasil analisis diketahui besarnya nilai Durbin Watson diperoleh pada PT. Pegadaian (Persero) Area Pontianak sebesar 1,985 dan pada PT. Finansia Multi Finance Pontianak sebesar 1,804. Nilai ini akan dibandingkan dengan nilai Durbin 
Watson pada tabel yang telah ditentukan maka data yang digunakan tidak terjadi autokorelasi karena nilainya lebih besar (Suliyanto, 2008).

Tabel 8. Hasil Uji Autokorelasi PT. Pegadaian (Persero) Area Pontianak

\begin{tabular}{ccc}
\hline $\mathrm{d}_{\mathrm{L}}$ & $\mathrm{d}_{\mathrm{U}}$ & Durbin-Watson \\
1,53 & 1,47 & 1,985 \\
\hline
\end{tabular}

Tabel 9. Hasil Uji Autokorelasi PT. Finansia Multi Finance Pontianak

\begin{tabular}{ccc}
\hline $\mathrm{d}_{\mathrm{L}}$ & $\mathrm{d}_{\mathrm{U}}$ & Durbin-Watson \\
1,23 & 1,26 & 1,804 \\
\hline
\end{tabular}

Hasil uji multikolinieritas (Tabel 10 dan 11) menunjukkan bahwa nilai statistik Tolerance yang didapat untuk model regresi ini adalah kurang dari 10. Nilai tersebut dapat dinyatakan bahwa tidak terdeteksi adanya masalah multikolinieritas karena nilai Tolerance yang dihasilkan tidak kurang dari 0,1 serta nilai VIF tidak lebih dari 10. Hal ini menunjukkan bahwa tidak terjadi kemiripan antara variabel satu dengan variabel lainnya atau dengan kata lain tidak ada korelasi yang kuat antara variabel independen yang satu dengan variabel independen lainnya sehingga model regresi layak digunakan dalam penelitian ini.

Tabel 10. Variance Inflating Factor (VIF) masing-masing Variabel Bebas PT. Pegadaian (Persero) Area Pontianak

\begin{tabular}{lc}
\hline Variabel bebas & Nilai VIF \\
\hline Servant Leadership & 1,215 \\
Kepuasan Kerja & 1,215 \\
\hline
\end{tabular}

Tabel 11. Variance Inflating Factor (VIF) masing-masing Variabel Bebas PT. Finansia Multi Finance Pontianak

\begin{tabular}{lc}
\hline Variabel bebas & Nilai VIF \\
\hline Servant Leadership & 1,053 \\
Kepuasan Kerja & 1,053 \\
\hline
\end{tabular}

Hasil uji asumsi heteroskedastisitas servant leadership dan kepuasan kerja terhadap kinerja karyawan pada PT/ Pegadaian (Persero) Area Pontianak disajikan pada gambar 3 dan hasil uji asumsi heteroskedastisitas pada PT. Finansia Multi Finance Pontianak disajikan pada gambar 4. Dari hasil analisis gambar scatterplot menunjukkan bahwa tidak terjadi perbedaan variance residual periode pengamatan ke periode pengamatan yang lain sehingga model regresi layak untuk digunakan. 


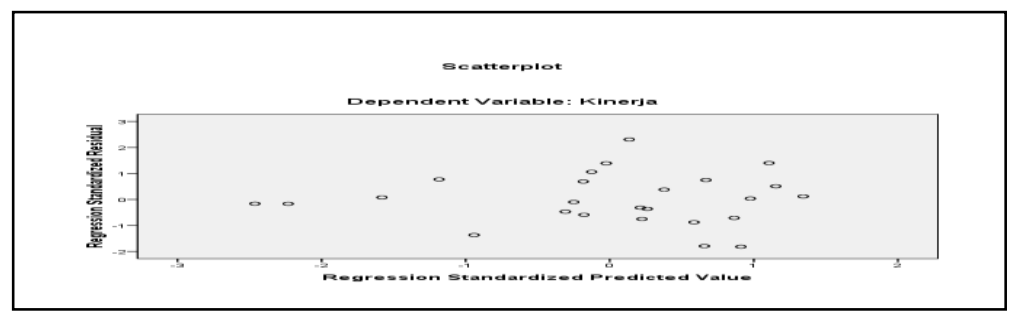

Gambar 3. Grafik Scatterplot PT. Pegadaian (Persero) Area Pontianak

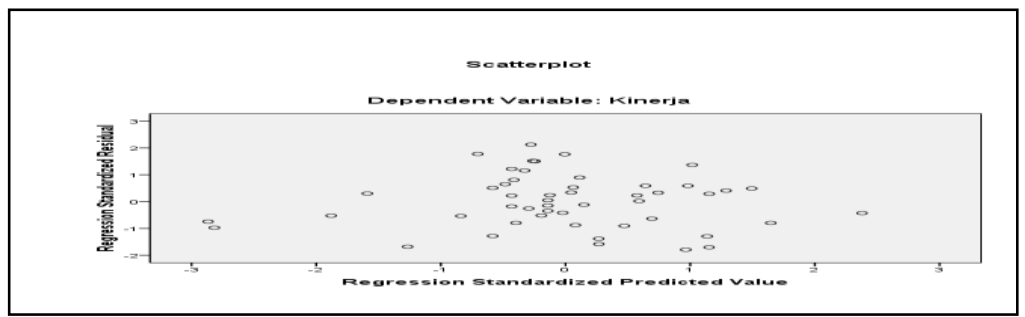

Gambar 4. Grafik Scatterplot PT. Finansia Multi Finance Pontianak

\subsection{Analisis Regresi Linear Berganda}

Hasil analisis tentang pengaruh variabel-variabel bebas yaitu servant leadership dan kepuasan karyawan terhadap kinerja karyawan pada PT. Pegadaian (Persero) Area Pontianak dan PT. Finansia Multi Finance Pontianak dapat dilihat pada Tabel 12 dan 13. Berdasarkan perhitungan dengan bantuan program SPSS menggunakan Full Model Regression diperoleh persamaan regresi liner berganda adalah sebagai berikut:

$$
Y=-17,543+0,181 X_{1}+0,700 X_{2}
$$

Berdasarkan Tabel 12 diketahui koefisien determinasi $\left(\mathrm{R}^{2}\right)$ adalah sebesar 0,475 yang berarti bahwa variabel bebas mampu menjelaskan model sebesar $47,5 \%$ sedangkan sisanya $(52,5 \%)$ dijelaskan oleh variabel lain yang tidak terdapat dalam model regresi ini. Hasil analisis regresi diperoleh nilai $\mathrm{F}$ hitung sebesar 21,266 dengan signifikan $\mathrm{F}$ sebesar $0,000<5 \%$. Hal ini memperlihatkan bahwa $\mathrm{H}_{0}$ ditolak dan $\mathrm{H}_{1}$ diterima dimana artinya secara bersama-sama kedua faktor sebagai variabel bebas $(\mathrm{X})$ berpengaruh positif terhadap variabel terikat (Y).

Tabel 12. Rekapitulasi Hasil Analisis Regresi Berganda PT. Pegadaian (Persero) Area Pontianak

\begin{tabular}{lrrrr}
\hline \multicolumn{1}{c}{ Model } & Unstandardized Coefficients & Standardized Coefficients & $\mathrm{t}$ & Sig. \\
\hline (Constant) & $-17,543$ & & -1.735 & 0,089 \\
Servant Leadership & 0,181 & 0,147 & 1.259 & 0,214 \\
Kepuasan kerja & 0,700 & 0,615 & 5.275 & 0,000 \\
$\mathrm{R}=0,689$ & & & F hitung $=21,266$ \\
$\mathrm{R}$ Square $\left(\mathrm{R}^{2}\right)=0,475$ & & & \\
$\mathrm{~N}=50$ & & & & \\
Siginifikan $=0,05(5 \%)$ & & & \\
\hline
\end{tabular}


Tabel 13. Rekapitulasi Hasil Analisis Regresi Berganda PT. Finansia Multi Finance Pontianak

\begin{tabular}{lrrrr}
\hline \multicolumn{1}{c}{ Model } & Unstandardized Coefficients & Standardized Coefficients & $\mathrm{t}$ & \multicolumn{1}{c}{ Sig. } \\
\hline (Constant) & $-3,000$ & & -0.249 & 0,804 \\
Servant leadership & 0,250 & 0,131 & 1.914 & 0,062 \\
Kepuasan kerja & 0,451 & 0,145 & 3.103 & 0,003 \\
$\mathrm{R}=0,513$ & & & F hitung $=8,399$ \\
$\mathrm{R}$ Square $\left(\mathrm{R}^{2}\right)=0,263$ & & & & \\
$\mathrm{~N}=50$ & & & & \\
Siginifikan $=0,05(5 \%)$ & & & & \\
\hline
\end{tabular}

Berdasarkan perhitungan dengan bantuan program SPSS menggunakan Full Model Regression diperoleh persamaan regresi liner berganda adalah sebagai berikut:

$$
\mathrm{Y}=-3,000+0,250 \mathrm{X}_{1}+0,451 \mathrm{X}_{2}
$$

Berdasarkan Tabel 13 diketahui koefisien determinasi $\left(\mathrm{R}^{2}\right)$ adalah sebesar 0,263 yang berarti bahwa variabel bebas mampu menjelaskan model sebesar 26,3\% sedangkan sisanya $(73,7 \%)$ dijelaskan oleh variabel lain yang tidak terdapat dalam model regresi ini. Hasil analisis regresi diperoleh nilai $\mathrm{F}$ hitung sebesar 8,266 dengan signifikan $\mathrm{F}$ sebesar $0,000<5 \%$. Hal ini memperlihatkan bahwa $\mathrm{H}_{0}$ tolak dan $\mathrm{H}_{1}$ diterima dimana artinya secara bersama-sama kedua faktor sebagai variabel bebas $(\mathrm{X})$ berpengaruh positif terhadap variabel terikat (Y).

\section{KESIMPULAN}

Hasil penelitian ini membuktikan dugaan hipotesis dapat diterima yaitu dimana Servant Leadership dan Kepuasan Kerja berpengaruh signifikan terhadap Kinerja Karyawan pada Lembaga Keuangan Non Bank di Pontianak dalam penelitian ini adalah PT. Pegadaian (Persero) Area Pontianak dan PT. Finansia Multi Finance Pontianak. Berdasarkan hasil penelitian juga ditemukan bahwa asumsi kedua variance sama besar (equal variances assumed) terpenuhi maka dapat menggunakan hasil uji-t dua sampel independen dengan asumsi kedua variance sama (equal variances assumed) untuk hipotesis yang memberikan nilai $t=1,322$ dengan derajat kebebasan $\mathrm{n}_{1}+\mathrm{n}_{2}-2=50+$ $50-2=98$ dan $p$-value $(2$-tailed $)=0,189$. Karena melakukan uji hipotesis satu sisi (one tailed), maka nilai $p$-value (2-tailed) harus dibagi dua menjadi 0,047/2 =0,0235. Karena $p$-value $=0,0235$ lebih kecil dari $\alpha=0,05$ maka $H_{0}$ diterima. Sehingga dapat disimpulkan bahwa rerata skor kinerja PT. Pegadaian (Persero) Area Pontianak lebih baik dibandingkan dengan rerata skor kinerja PT. Finansia Multi Finance Pontianak. 


\section{DAFTAR PUSTAKA}

Mangkunegara, A.P. (2005). Evaluasi Kinerja Sumber Daya Manusia. Bandung : Penerbit PT. Refika Aditama.

Mangkunegara, A.P. (2008). Perilaku dan Budaya Organisasi, Cetakan kedua. Bandung : Penerbit PT.Refika Aditama.

Bernardin H, J., \& Russel, E.A. (2010). Human resources Management : An Experiental Approach Edition 5. New York: McGraw-Hill Inc.

Cokroaminoto. (2007). Membangun Kinerja Karyawan melalui Perbaikan Lingkungan Kerja. Diakses dari http://cokroaminoto.wordpress.com.

Dennis, R. (2004). Development of the Servant Leadership Assessment Instrument. Dissertation Abstract International, 05, 18-57.

Gibson, Ivancevich, Donnelly \& Konopaske. 2006. Organization : Behaviour \& Structure. New York : McGraw Hill.

Greenleaf, R.K. (1997). Servant Leadership: A Journey Into The Nature of Legitimate Power and Greatness. Mahwah, NJ: Paulist Press.

Greenleaf, R.K. (1998). Servant Leadership in L.C. Spears (Ed). Insight on Leadership: Service, Stewardship, Spirit and Servant-Leadership. New York: Wiley.

Hasibuan, M. (2006). Manajemen Sumber Daya Manusia. Jakarta : Bumi Aksara.

Liden, R.C., Wayne, S.J., Zhao, H., \& Henderson, D. (2008). Servant leadership: development of a multidimensional measure and multi-level assessment. The Leadership Quarterly, 19, 161-177.

Luthans, F. (2006). Organizational Behaviour 10th Edition. New York : McGraw-Hill.

Mathis, R.L., \& Jackson, J.H. (2002). Manajemen Sumber Daya Manusia. Penerjemah J.Sadeli \& B.Prawira. Jakarta: Penerbit Salemba Empat.

Mathis, R.L., \& Jackson, J.H. (2004). Human Resources Management, $10^{\text {th }}$ Edition. Penerjemah D.Angelica. Jakarta: Penerbit Salemba Empat.

Robbins, S.P. (2001). Perilaku Organisasi, Konsep, Kontroversi, Aplikasi, Versi Bahasa Indonesia, edisi kedelapan. Jakarta: PT. Prenhalindo.

Smith, C. (2005). Servant Leadership: The Leadership Theory of Robert K. Greenleaf. Info 640 - MGMT.OF INFO.ORGS.

Spears, L.C. (2010). Character and Servant Leadership: Ten Characteristics of Effective, Caring Leaders. The Journal of Virtues \& Leadership, 1, 25-30.

Sudarmanto. (2009). Kinerja dan Pengembangan Kompetensi SDM. Yogyakarta : Pustaka Pelajar. 
Sugiyono. (2007). Metode Penelitian Bisnis. Bandung: Alfabeta.

Sugiyono. (2013). Metode Penelitian Manajemen. Pendekatan: 1. Kuantitatif; 2. Kualitatif; 3. Mixed Methods; 4. Action Research; 5. Penelitian Evaluasi. Bandung: Alfabeta.

Umar, H. (2008). Riset Sumber Daya Manusia Dalam Organisasi. Jakarta: PT. Gramedia Pustaka Utama. 